\title{
KONSEP DIRI REMAJA DARI KELUARGA BROKEN HOME
}

\author{
Chiktia Irma Oktaviani \\ Siti Mahmudah \\ Fakultas Psikologi \\ Universitas Islam Negeri (UIN)Maulana Malik Ibrahim Malang \\ Jl. Gajayana 50 Malang Telp. 0341-558916
}

\begin{abstract}
Abstrak-Adolescence is a period of transition or the transition from childhood into adulthood. At this time individuals experiencing various changes, both physically and psychologically. This study aims yo determine the self-concept teen from a broken home. The method used was a qualitative research method. Data collection using interviews, observation and documentation. Subject used in the study were adolescents who experienced a broken home. The result of this study are the self-concept of adolescents who experience a broken home leads to positive. Factors that can affect an individuals self-concept formation is significant other who could be close friends or family, the environment, the role of social factors and physical state is of note primarily by teenagers and a factor that was instrumental in the formation of an individual self-concept.
\end{abstract}

\section{Keywords : Adolescence Self-Concept, Broken Home Family}

PSIKOISLAMIKA. Jurnal Psikologi Islam (JPI) copyright @ 2014 Laboratorium Penelitian, Kajian Psikologi Islam dan Penerbitan. Volume 11. Nomor 1, Tahun 2014

\section{PENDAHULUAN}

Masa remaja dapat dipandang sebagai suatu masa dimana individu dalam proses pertumbuhannya (terutama fisik) telah mencapai kematangan. Masa ini menunjukan suatu masa kehidupan, dimana kita sulit untuk memandang remaja itu sebagai kanak-kanak, tapi tidak juga sebagai orang dewasa. Mereka tidak dapat dan tidak ingin lagi diperlakukan sebagai kanak-kanak.Sementara itu mereka belum mencapai kematangan yang lebih dan tidak dapat dimasukan ke dalam kategori orang dewasa. Konsep diri adalah kumpulan keyakinan dan persepsi diri terhadap diri sendiri yang terorganisir. Dengan kata lain, konsep diri tersebut bekerja sebagai skema dasar (Baron dan Byrne, 2004). Konsep diri terbagi menjadi dua, yaitu positif dan negatif. Individu yang merasa dirinya diterima akan cenderung memiliki konsep diri yang positif dan sebaliknya, orang yang merasa dirinya ditolak akan cenderung memiliki konsep diri yang negatif (Calhoun, 1995). Faktor pembentuk konsep diri remaja adalah orang tua, teman sebaya, masyarakat dan belajar (Baldwin dan Holmes dalam Pardede, 2008).
Hal ini membuat remaja menjadi pribadi yang labil dan semakin terlihat pada remaja broken home. Pada masa remaja ini juga terjadi pembentukan konsep diri. Proses pembentukan konsep diri ini terjadi secara alami dan seharusnya terjadi pada masa-masa remaja. Broken home adalah kurangnya perhatian dari keluarga atau kurangnya kasih sayang dari orang tua sehingga membuat mental seorang anak menjadi frustasi, brutal dan susah diatur. Broken home sangat berpengaruh besar pada mental remaja saat sekarang.

Konsep diri remaja yang mengalami broken home tentunya berbeda, karena remaja tersebut mengalami situasi yang berbeda dari remaja lain secara umum. Adapun tujuan dari penelitian ini adalah untuk megetahui konsep diri remaja yang mengalami broken home.

\section{KERANGKA KERJA TEORITIK}

Konsep diri adalah pandangan dan perasaan individu tentang dirinya baik yang sifatnya psikologis, sosial maupun fisik (Rakhmat, 2003). Konsep diri sendiri merupakan gambaran yang dimiliki individu tentang 
dirinya yang dibentuk melalui pengalaman-pengalaman yang diperoleh dari interaksi lingkungan. Definisi lain menyebutkan bahwa konsep diri merupakan semua perasaan dan pemikiran individu mengenai dirinya sendiri. Hal ini meliputi kemampuan, karakter diri, sikap, tujuan hidup, kebutuhan dan penampilan diri (Keliat, 1992).

Konsep diri merupakan aspek penting dalam diri individu, karena konsep diri individu merupakan kerangka acuan (frame of reference) dalam berinteraksi dengan lingkungan (Fitts, 1971 dalam Agustiani, 2006).Dasar dari konsep diri individu ditanamkan pada saat-saat dini kehidupan anak dan menjadi dasar yang memengaruhi tingkah lakunya di kemudian hari.

Konsep diri merupakan apa yang dilihat, dirasakan dan dipikirkan oleh individu mengenai dirinya sendiri secara menyeluruh sehingga tampak dalam perilaku individu. Konsep diri berpengaruh kuat terhadap tingkah laku individu. Dengan mengetahui konsep diri individu, kita akan lebih mudah meramalkan dan memahami tingkah laku orang tersebut.

Para ahli psikologi juga berbeda pendapat dalam menetapkan dimensi-dimensi konsep diri. Dimensi konsep diri dengan beberapa istilah (Cenci, 1993), yakni:

1. Dimensi gambaran diri (sell image)

2. Dimensi penilaian diri (self-evaluation)

3. Dimensi cita-cita diri (self-ideal)

Konsep diri dalam dua dimensi pokok (Fitts, 1971 dalam Agustiani, 2006), yaitu sebagai berikut:

1. Dimensi Internal

Dimensi Internal atau yang disebut juga kerangka acuan internal (internal frame of reference) adalah penilaian yang dilakukan individu yakni penilaian yangdilakukan individu terhadap dirinya sendiri berdasarkan dunia di dalam dirinya. Dimensi ini terdiri dari tiga bentuk:

a. Diri Identitas (Identity Self)

Bagian diri ini merupakan aspek yang paling mendasar pada konsep diri dan mengacu pada pertanyaan "Siapakah saya?".

b. Diri Pelaku (Behavioral Self)

Diri pelaku merupakan persepsi individu tentang tingkah lakunya yang berisikan segala kesadaran mengenai "Apa yang dilakukan oleh diri?".

c. Diri Penerimaan / Penilai (Judging Self) Diri penilai berfungsi sebagai pengamat, penentu standar dan evaluator. Kedudukannya adalah sebagai perantara (mediator) antara diri identitas dan diri pelaku.

2. Dimensi Eksternal

Pada dimensi eksternal, individu menilai dirinya melalui hubungan dan aktivitas sosialnya, nilai-nilai yang dianutnya, serta hal-hal lain di luar dirinya. Dimensi ini merupakan suatu hal yang luas, misalnya diri yang berkaitan dengan sekolah, organisasi, agama dan sebagainya. Namun, dimensi yang dikemukakan oleh Fitts adalah dimensi eksternal yang bersifat umum bagi semua orang dan dibedakan atas lima bentuk, yaitu:

a. Diri Etik-moral (Moral-ethical Self)

Merupakan persepsi individu terhadap dirinya dilihat dari standar pertimbangan nilai moral dan etika.

b. Diri Fisik (Physical Self)

Diri fisik menyangkut persepsi individu terhadap keadaan dirinya secara fisik. Dalam hal ini individu dapat menerima keadaan fisik yang dimilikinya.

c. Diri Sosial (Social Self)

Keadaan atau penilaian individu terhadap interaksi dirinya dengan orang lain yang terjadi di dalam masyarakat atau di dalam bersosialisasi.

d. Diri Keluarga (Family Self)

Keadaan, perasaan dan harga diri individu dalam kedudukannya sebagai anggota keluarga.

e. Diri Pribadi (Personal Self)

Sikap individu terhadap dirinya baik secara sadar maupun tidak sadar. Hal ini tidak dipengaruhi oleh kondisi fisik atau hubungan dengan orang lain, tetapidipengaruhi oleh sejauh mana individu merasa puas terhadap pribadinya atau sejauh mana ia merasa dirinya sebagai pribadi yang tepat.

Konsep diri individu dapat dipengaruhi oleh beberapa faktor sebagai berikut:

1. Pengalaman, terutama pengalaman interpersonal, yang memunculkan perasaan positif dan perasaan berharga.

2. Kompetensi dalam area yang dihargai oleh individu dan orang lain.

3. Aktualisasi diri atau implementasi dan realisasi dari potensi pribadi yang sebenarnya (Fitts, 1971 dalam Agustiani, 2006).

Menurut beberapa pendapat para ahli dapat dikategorikan kedalam dua faktor yaitu terdiri dari faktor internal dan eksternal. Beberapa hal yang memengaruhi konsep diri individu adalah: 
a) Teman Sebaya

b) Sekolah

c) Orang Tua

d) Saudara Sekandung

e) Masyarakat

f) Pengalaman

Dalam perkembangan konsep diri terbagi atas dua yaitu, konsep diri positif dan konsep diri negatif (Calhoun dan Acocella, 1990).

\section{Konsep Diri Positif}

Konsep diri bersifat stabil dan bervariasi. Individu yang memiliki konsep diri yang positif adalah individu yang tahu betul tentang dirinya, sehingga evaluasi terhadap dirinya sendiri menjadi positif dan dapat menerima keberadaan orang lain. Ada empat tanda orang yang mempunyai konsep diri positif (Brooks dan Emmert dalam Rakhmat, 2007), yaitu:

a. la menerima pujian tanpa rasa malu. la menyadari bahwa setiap orang mempunyai perasaan, keinginan dan perilaku yang tidak seluruhnya disepakati masyarakat.

b. Mampu memperbaiki dirinya karena ia sanggup mengungkapkan aspek-aspek kepribadian yang tidak disenangi dan berusaha mengubahnya.

c. Merasa setara dengan orang lain.

d. Yakin akan kemampuan yang dimiliki untuk mengatasi masalah.

2. Konsep Diri Negatif

Terdiri dari dua tipe yaitu, dimana pandangan individu tentang dirinya benar-benar tidak teratur, tidak memiliki perasaan kestabilan dan keutuhan diri. Individu tersebut tidak tahu tentang dirinya, mempunyai kekuatan dan kelemahan atau apa yang dihargai dalam kehidupannya. Ada lima tanda orang yang memiliki konsep diri negatif (Brooks dan Emmert dalam Rakhmat, 2007), yaitu:

a. Merasa tidak disenangi orang lain, merasa tidak diperhatikan.

b. Pesimis terhadap kompetisi, enggan untuk bersaing dengan orang lain dalam prestasi.

c. Peka terhadap kritik, tidak dapat menerima kritik dan mudah marah. Seringkali menganggap bahwa koreksi seringkali dipersepsi sebagai usaha untuk menjatuhkan harga dirinya.

d. Hiperkritis terhadap orang lain, cenderung mengeluh, mencela atau meremehkan apapun dan siapapun. e. Responsif sekali terhadap pujian. Walaupun ia mungkin berpura-pura menghindari pujian.

f. Konsep diri terbagi menjadi beberapa bagian (Stuart dan Sundeen dalam Keliat, 1992), yang terdiri dari:

Perspektif tentang konsep diri dijelaskan pula pada agama Islam. Islam merupakan agama dengan garis aturan yang sudah tertata rapi untuk kemakmuran umatnya. Segala aturan-aturan yang terkandung di dalamnya termuat Al-Qur'an dan Hadist. Tentunya kajian-kajian yang ada di dalamnya mencakup segala aspek, baik dalam kehidupan bersosial, tata cara bertingkah laku, pedoman hidup umat manusia, dan kepribadian manusiapun juga tidak terlewatkan. Sikap-sikap seperti aspek yang terdapat dalam konsep diri manusia serta perilaku yang seharusnya di tanamkan oleh kaum muslimin yaitu menjauhi sikap-sikap tercela.Ayat yang menerangkan tentang konsep diri diantaranya, QS.Al-Hujuraat ayat 11, QS.At Tiin ayat 4 dan 5, dan QS.Ali Imran ayat 139.

Konsep diri remaja merujuk pada evaluasi yang menyangkut bidang-bidang tertentu dari diri remaja tersebut. Remaja melakukan evaluasi diri dalam berbagai bidang.Misal, bidang akademik, atletik, penampilan fisik dan sebagainya. Konsep diri ini hampir sama dengan harga diri. Namun, harga diri diartikan sebagai martabat diri atau gambaran diri yaitu suatu dimensi global dari diri. Para peneliti tidak selalu membuat pembedaan yang jelas antara harga diri dengan konsep diri, mereka terkadang mencampur-adukan istilah-istilah tersebut atau tidak membuat definisi yang sama (Dusek dan McIntyre, 2003; Harter, 2006 dalam Santrock, 2007).

Sebagai contoh, konsep diri remaja dapat mengindikasikan persepsi mengenai apakah ia inteligen dan menarik atau tidak, meskipun persepsi itu mungkin tidak tepat. Dengan demikian, konsep diri remaja yang tinggi dapat merujuk pada persepsi yang tepat dan benar mengenai martabatnya sebagai seorang pribadi, termasuk keberhasilan dan pencapaiannya.

Namun konsep diri remaja yang tinggi juga dapat mengindikasikan penghayatan mengenai superioritasnya terhadap orang lain, yang sombong, berlebihan dan tidak beralasan. Dengan cara yang sama, konsep diri remaja yang rendah dapat mengindikasikan persepsi yang tepat mengenai keterbatasan atau penyimpangan, atau bahkan kondisi tidak aman dan inferior yang akut. 
Menurut Kamus Besar Bahasa Indonesia (1994), keluarga terdiri dari ayah, ibu dan anak (keluarga inti). Lingkungan keluarga memberikan pengaruh besar terhadap perkembangan jiwa anak. Keluarga merupakan unit sosial terkecil yang memberikan pondasi primer bagi perkembangan anak.Sedang lingkungan sekitar dan sekolah hanya memberikan nuansa pada perkembangan anak. Karena itu baik-buruknya struktur keluarga dan masyarakat sekitar memberikan pengaruh baik atau buruknya pertumbuhan kepribadian anak (Gunarsa dan Gunarsa, 1995 dalam Kartono, 1992). Ada beberapa fungsi keluarga yaitu sebagai tempat bernaung yang teduh, tempat belajar, tempat menjalin komunikasi, tempat kesenjangan, dan tempat belajar beribadah.

Broken home merupakan kondisi dimana keluarga yang terdiri dari ayah, ibu dan anak tidak lagi bersatu. Ayah dan ibu secara ideal tidak terpisah tetapi bahu membahu dalam melaksanakan tanggung jawab sebagai orang tua dan mampu memenuhi tugas sebagai pendidik. Konsep diri yang terjadi pada remaja yang keluarganya mengalami broken home tentunya membuat mereka memiliki rasa minder, tidak percaya diri, takut, malu dan sebagainya. Tentunya hal ini akan membuat seorang remaja mengalami tidak nyaman dengan kondisi tersebut yang pada kenyataannya dialami terhadap keluarganya. Mungkin ada beberapa yang terkesan biasa saja dan menjalin hidup dengan kondisi demikian serta tetap tabah atau sabar.

\section{METODE}

Untuk mendapatkan pemahaman mendalam dan khusus atas suatu fenomena serta untuk memahami manusia dalam segala kompleksitasnya sebagai makhluk yang subjektif, maka pendekatan kualitatif adalah pendekatan yang paling sesuai untuk digunakan (Poerwandari, 2001). Dalam penelitian kualitatif juga digunakan analisis induktif dimana peneliti tidak memaksa diri untuk hanya membatasi penelitian pada upaya menerima atau menolak dugaannya, melainkan mencoba memahami situasi (make sense of the situation) sesuai dengan bagaimana situasi tersebut menampilkan diri.

Subjek dalam penelitian ini adalah remaja yang mengalami broken home di UIN Maulana Malik Ibrahim Malang. Sedangkan teknik pengambilan sampel yang digunakan dalam penelitian ini adalah random sampling dengan kriteria sebagai berikut:

a. Subjek seorang remaja

b. Dari keluarga broken home c. Bertempat tinggal/kost di daerah Malang

Metode pengumpulan data dalam penelitian ini menggunakan metode wawancara dan observasi sebagai metode utama penelitian. Analisis data adalah proses mengatur urutan data, mengorganisasikannya ke dalam suatu urutan pola, kategori dan satu uraian dasar (Patton dalam Poerwandari, 2001). Permasalahan yang muncul akan dianalisis dengan menggunakan empat unsur sebagai satu sistem yaitu, survey, reduksi data, penyajian data dan penarikan kesimpulan.

\section{HASIL}

Analisis data menunjukan bahwa kedua remaja yang mengalami broken home tersebut memiliki gambaran konsep diri yang berbeda-beda. Secara keseluruhan konsep diri dapat dibagi menjadi dua, yaitu konsep diri negatif dan konsep diri positif. Berdasarkan hasil wawancara maupun observasi terhadap kedua subek tersebut, secara garis besar kedua subjek menunjukan konsep diri yang mengarah pada konsep diri positif.

Seluruh sikap dan pandangan individu terhadap dirinya sangat memengaruhi individu dalam menafsirkan pengalamannya.Sebuah kejadian dapat ditafsirkan secara berbeda-beda oleh tiap individu, karena masing-masing mempunyai sikap dan pandangan yang berbeda terhadap diri sendiri (Pudjijogyanti, 1993). Konsep diri yang dimiliki individu dilakukan dari proses belajar dengan melihat reaksi-reaksi orang lain terhadap perbuatan yang telah dilakukan, melakukan perbandingan dirinya dengan orang lain, memenuhi harapan-harapan orang lain atas peran yang dimaninkan serta melakukan identifikasi terhadap orang yang dikaguminya (Hurlock, 1997). Kondisi broken home yang dialami kedua remaja tersebut ditafsirkan secara berbeda oleh masing-masing individu dan setiap pengalaman yang menyertai hal itu ditafsirkan secara berbeda olehnya sehingga menghasilkan pembentukan konsep diri yang berbeda meskipun akhirnya kedua subjek mengarah pada konsep diri yang positif.

\section{KESIMPULAN}

Konsep diri etik-moral subjek keduanya mengarah ke konsep diri positif.Konsep diri fisik kedua subjek sama-sama mempunyai anggota tubuh yang lengkap, mempunyai tinggi badan yang tidak terlalu tinggi dan tidak terlalu pendek, bertubuh sedang tidak gemuk dan tidak kurus, mempunyai warna kulir sawo matang, dan mempunyai paras wajah yang cantik. Konsep diri sosial subjek 1 dan 
subjek 2 sedikit berbeda.Akan tetapi masyarakat mempunyai penilain sendiri terhadap kedua subjek. Subjek 1 lebih dipercaya dan diberi kebebasan berteman dengan siapapun.Subjek 2 kurang bisa beradaptasi atau bergaul dengan masyarakat, oleh karenanya masyarakat menilai subjek 2 lebih cuek atau sedikit sombong.Konsep diri keluarga subjek 1 dan subjek 2 mengarah ke positif.

\section{DAFTAR PUSTAKA}

Agustiani, Hendriati. 2006. Psikologi Perkembangan; Pendekatan Ekologi Kaitannya dengan Konsep Diri dan Penyesuaian Diri pada Remaja. Bandung: Aditama.

Baron, Robert \& Byrne. 2004. Psikologi Sosial (edisi kesepuluh). Jakarta: Erlangga.

Calhoun, F \& Acocella, J. 1995.Psikologi Tentang Penyesuaian dan Hubungan Kemanusiaan (edisixketiga). Semarang: IKIP Semarang.

Desmita. 2007. Psikologi Perkembangan. Bandung: PT. Remaja Rosdakarya.

Gunarsa, Singgih \& Singgih, Yulia, D. G. 1983. Psikologi Perkembangan Anak dan Remaja. Jakarta: PT. BPK Gunung Mulia.

Hurlock, E. B. 1997. Psikologi Perkembangan : Suatu Pendekatan Sepanjang Rentang Kehidupan. Jakarta: Erlangga.

Keliat, Anna. 2009. Gangguan Konsep Diri. Jakarta:
Adapun untuk remaja yang mengalami broken home keadaannya tidak selalu berkonotasi negatif, seseorang yang berlatar belakang broken home bisa memiliki banyak prestasi yang tinggi.Percaya diri yang tinggi, dan mampu mengembangkan potensi diri dengan rajin dan dapat mengasah keterampilan. Mengikuti kegiatan organisasi atau kegiatan yang melibatkan diri untuk berperan dalam kelompok. Menjalin komunikasi yang baik dan terbuka dengan keluarga.

Penerbit Buku Kedokteran EGC.

Pardede, Y. O. K. 2008. Konsep Diri Anak Jalanan Usia Remaja. Jurnal Psikologi. Volume 1 No.2 Juni 2008.

Poerwandari, E. K. 2001. Pendekatan Kualitatif dalam Penelitian Psikologi. Jakarta: Lembaga Pengembangan Sarana Pengukuran dan Pendidikan Psikologi Universitas Indonesia.

Rakhmat, Jalaluddin. 2007. Psikologi Komunikasi. Bandung: Remaja Rosdakarya.

Santrock, John W. 2003. Life Span Development (edisi kelima). Jakarta: Erlangga.

Sobur, Alex. 2003. Psikologi Umum. Bandung: Pustaka Setia.

Stuart, G. W \& Sundeen, S. J. 1998. Buku Saku Keperawatan Jiwa. Jakarta: EGC.

Vitasandy, Tutut Dian \& Zulkaida, A. 2010. Konsep Diri Pria Biseksual. Jurnal Psikologi Volume 3.No.2. 


\section{MANUAL PENULISAN}

Psikoislamika, Jurnal Psikologi Islam (JPI) menerima tulisan berupa hasil penelitian, artikel, dan resensi buku, dalam bahasa Indonesia maupun Inggris, dengan ketentuan sebagai berikut:

1. Naskah bersifat orisinil dan belum pernah 1 . dipublikasikan dalam media lain.

2. Dapat dikirim melalui email dengan panjang 2. tulisan antara 4500-5000 kata.

3. Naskah untuk resensi buku tidak lebih 10003. kata.

4. Sumber kutipan dan rujukan dicantumkan 4 . secara jelas dengan menggunakan in note, disertakan dengan tatacara penulisan APA (American Psychological Association) atau dapat menggunakan fasilitas penulisan rujukan di Microsoft Office.

5. Naskah yang akan dipublikasikan, terlebih 5 . dahulu diputuskan melalui dewan redaksi dan bagi naskah yang diterima akan dikomunikasikan lebih lanjut. Tulisan tidak memenuhi kualifikasi dewan redaksi, pengirim naskah akan diberitahu namun tanpa mengembalikan naskah aslinya.

6. Bagi naskah yang diterima, penulis diharapkan 6. memenuhi beberapa kriteria yang telah ditentukan oleh redaksi. Oleh karena itu, penulis naskah diharapkan memenuhi standar aturan penulisan yang telah ditentukan atau melakukan revisi jika dewan redaksi memberikan umpan balik.

7. Menyertakan curiculum vitae singkat (maksimal 7. 50 kata), jabatan/pekerjaan sekarang, nama lembaga tempat bekerja, nomor telepon dan alamat email penulis.

Sistematika dan isi naskah untuk penelitian memuat sejumlah kriteria subjudul sebagai berikut:

Abstrak. Memuat setidaknya tujuan, teori, metode, analisis dan kesimpulan hasil penelitian. Ditulis dalam bahasa Inggris untuk tulisan yang berbahasa Indonesia dengan komposisi maksimal 150 kata dan disertai katakunci.

Muqadimah. Memuat latarbelakang masalah dan tujuan penelitian terkait dengan penelitian sebelumnya.
Menghindari format penulisan model tesis atau disertasi agar tidak terkesan formal. Muqadimah maksimal ditulis tidak lebih dari 3 paragraf.

Kerangkakerja teoritik (conceptual framework). Mendeskripsikan kerangka kerja teori penelitian secara padat dan penurunan hipotesisnya (jika ada). Ditulis secara langsung menjadi satu kesatuan (tidak terpisah).

Metode. Mencakup; sampel, instrument (alat penelitian) dan langsung dijelaskan analisis validitas dan reliabilitas, prosedur penentuan responden atau tatacara pengambilan data dan informasi teknik analisis data.

Hasil. Mendeskripsikan cakupan hasil analisis statistik untuk menjawab pembuktian hipotesis mayor atau minor.

Diskusi. Memungkinkan verifikasi teori atau memperkuat dengan membandingkan teori, membahas dialektikan sub-sub variabel hasil analisis, membuat penegasan, menyarankan variabel tertentu karena alasan khusus dengan cara memperluas atau mempersempit kaidah atau sampai batas menyusun teori dari temuan penelitian.

Kesimpulan. Menegaskan pencapaian tujuan dan kesimpualn terhadap pembuktian hipotesis dan saran untuk pemanfaatan hasil penelitian dan bentuk tidak lanjut bagi penelitian selanjutnya.

Kategori penulisan opini ilmiah (theoritical overview), disarankan agar penulis menyajikan kerangka teoriteori yang lebih baru dan menyertakan pendapat pribadi dalam ulasan berbentuk diskusi.Bagi penulis yang berminat untuk meninjau buku (resensi) juga disertakan sejumlah kelebihan, manfaat dan timbangan kritis terhadap kekurangan dari pemikiran dalam buku yang sedang ditinjau.

\section{Submission}

Psikoislamika, Jurnal Psikologi Islam (JPI) untuk edisi mendatang. Redaksi mengundang kepada para pakar atau peneliti untuk ikut menjadi kontributor bagi pengembangan psikologi Islam dari berbagai perspektif kajian (interdisipliner), terutama pengembangan psikologi Islam yang berorientasi kepada pengembangan khazanah kesehatan mental melalui eksplisitasi nilai-nilai islam dan untuk tujuan kemaslahatan umat li kulli zaman wa makan. 